\title{
Serum leptin levels and GHR-d3/fl gene polymorphism in acromegalic patients with thyroid nodules
}

\author{
Senay Topsakal ${ }^{1, A-F}$, Fulya Akin ${ }^{1, A, C}$, Sabahat Turgut 2, C, Emrah Yerlikaya ${ }^{1, B}$, Guzin F. Yaylalii, B, C \\ 1 Department of Endocrinology and Metabolism, Pamukkale University, Denizli, Turkey \\ ${ }^{2}$ Department of Physiology, Pamukkale University, Denizli, Turkey \\ A - research concept and design; $\mathrm{B}$ - collection and/or assembly of data; $\mathrm{C}$ - data analysis and interpretation; \\ $D$ - writing the article; $E$ - critical revision of the article; $F$ - final approval of article
}

Address for correspondence

Senay Topsakal

E-mail: topsakals@hotmail.com

\section{Funding sources}

none declared

\section{Conflict of interest}

none declared

Received on June 9, 2014

Revised on 0ctober 15, 2014

Accepted on December 5, 2014

\begin{abstract}
Background. Acromegaly is a rare and serious syndrome that is commonly associated with pituitary neoplasms. Thyroid multinodular disease is a common finding in acromegaly. Leptin is a polypeptide hormone, and studies have shown that it can increase cell proliferation and inhibit apoptosis.
\end{abstract}

Objectives. The aim of the study was to determine the relationship of serum leptin levels with certain blood parameters and determine if growth hormone receptor (GHR)-d3/fl gene polymorphism is associated with thyroid nodules in acromegalic patients.

Material and methods. A total of 24 acromegalic patients with or without thyroid nodules were included in the study. Gene polymorphisms and blood parameters were examined.

Results. A marked increase was observed in serum leptin concentration in acromegalic patients with thyroid nodules compared to patients without them $(p<0.05)$. GH levels were lower in patients without nodules than in patients with nodules $(p<0.05)$. Blood glucose levels were higher in patients with nodules compared to those without them $(p<0.05)$, and the presence of thyroid nodules was associated with decreased blood low-density lipoprotein (LDL) levels compared to patients without nodules $(p<0.05)$. A significant relationship was observed between growth hormone receptor (GHR)-d3/fl gene polymorphism and leptin levels in acromegalic patients with thyroid nodules $(p<0.001)$.

Conclusions. These data from acromegalic patients indicate that thyroid nodules are associated with increased serum leptin, GH and blood glucose levels and with decreased LDL levels. GHR-d3/fl gene polymorphism status was strongly related to higher leptin levels.

Key words: thyroid, gene polymorphism, acromegaly, hormone, endocrinology

DOI

10.17219/acem/34793

Copyright

Copyright by Author(s)

This is an article distributed under the terms of the

Creative Commons Attribution Non-Commercial License

(http://creativecommons.org/licenses/by-nc-nd/4.0/) 
Acromegaly is associated with excessive secretion of growth hormone $(\mathrm{GH})$ and insulin-like growth factor-1 (IGF-1), resulting in bone overgrowth and an increase in soft tissue. ${ }^{1}$ Thyroid nodules are a common clinical problem in females. Epidemiological studies have shown the prevalence of palpable thyroid nodules to be approximately $5 \%$ in women and $1 \%$ in men living in iodine-sufficient parts of the world.,3 In contrast, high-resolution ultrasound can detect thyroid nodules in $19-67 \%$ of randomly selected individuals, with higher frequencies in women and the elderly. ${ }^{4}$ Thyroid enlargement can also be seen in acromegalic patients. ${ }^{5,6}$ Long-term elevation of serum GH levels in acromegaly is associated with goiter development and is probably caused by the mitogenic effects of IGF-1. ${ }^{7}$

Changes in enzyme activity may lead to somewhat higher serum triiodothyronine (T3) and lower reverse T3 (rT3) concentrations in patients with active acromegaly, although the levels are usually within physiological ranges. ${ }^{8,9}$ The prevalence rates of certain benign and malignant neoplasms are higher in acromegalic patients compared with the healthy population. ${ }^{10}$

Leptin is a potent anorexigenic hormone found in the anterior pituitary and secreted by adipose tissue in proportion to adipose content. It is a product of the obesity (Ob) gene that regulates both satiety and energy expenditure. ${ }^{11}$ Leptin is secreted with diurnal fluctuations, and greater secretion is observed in subjects who are obese or who have insulin resistance. ${ }^{12,13}$ While a negative influence of thyroid hormones on serum leptin concentrations has been described, some authors report no influence of thyroid hormones on leptin levels. ${ }^{14-17}$

There are many reports concerning the stimulatory effect of leptin on cell mitosis and its involvement in the carcinogenesis of breast, colon, prostate, lung, kidney and ovary cells. Studies have shown that leptin's abilities to increase cell proliferation and inhibit apoptosis are involved in creating certain types of tumors. ${ }^{18-24}$ Specifically, increased expression of leptin and its receptor are well documented in papillary thyroid cancer. Similar to other tumor types, some authors reported that leptin exerts oncogenic effects on papillary thyroid carcinoma cells by stimulating cell proliferation and inhibiting apoptosis. ${ }^{25-27}$

The principal regulator of GH sensitivity is the GH receptor (GHR) and consists of an extracellular domain of 246 amino acids, a single transmembrane domain, and a cytoplasmic domain. The encoding gene has 9 exons, but there are 2 isoforms of the GHR in humans generated by the deletion of exon 3 of the gene, resulting in 3 genotypes: homozygous GHR-fl, homozygous GHR-d3, and heterozygous GHR-d3/fl. ${ }^{28}$

\section{Objectives}

Acromegaly is frequently associated with thyroid enlargement, and the size is dependent on the duration of
GH excess. ${ }^{5,6}$ Thyroid multinodular disease is a common finding in acromegaly. $5,7,29,30$ The reported frequencies of diffuse goiter and nodular goiter in acromegalic patients are 78-92 and 63\%, respectively. ${ }^{5}$ Leptin, an Ob gene product, is secreted exclusively by adipocytes and regulates energy balance. Because GH modulates fat mass, it is possible that $\mathrm{GH}$ and chronic $\mathrm{GH}$ excess affects leptin. The aim of this study was to examine leptin levels in acromegalic patients, with or without thyroid nodules, and to identify any relationship with GHR gene polymorphism.

\section{Material and methods}

\section{Study design}

The study was performed according to the Helsinki Declaration and was approved by the Ethical Committee of Pamukkale University (09/198). All the patients and volunteers provided written acknowledgement of informed consent for participation. The study group included 24 patients with acromegaly (13 males, 11 females; mean age, $52.04 \pm$ standard deviation [SD] 9.46; range, 30-68 years), including 17 patients with thyroid nodules (9 males and 8 females; mean age, $51.05 \pm$ SD 9.66; range, 19-84 years) and 7 patients without thyroid nodules (4 males, 3 females; mean age, $46 \pm$ SD 17.6; range, 30-68 years). The participants' anthropometric measurements and blood parameters were evaluated.

The diagnosis of acromegaly was established on the basis of criteria proposed by Freda and confirmed by pathological examination of surgically resected tissues ${ }^{31}$. Clinical signs, magnetic resonance imaging (MRI), and $\mathrm{GH}$ and IGF-1 levels were assessed to support the diagnosis. Active acromegaly was associated with increased serum levels of GH and IGF-1, and modified sellar morphology visible on MRI, indicating the presence of a pituitary adenoma.

The main inclusion criteria were age over 18 years and the presence of acromegaly.

The patients included in the study were not surgically or medically treated for acromegaly (e.g. with somatostatin, dopamine analogs or GH receptor antagonists) at the time of inclusion in the study. Exclusion criteria included pregnancy, the use of any drugs at the time of the study or current surgical treatment for thyroid nodules. On this basis 11 patients were excluded from the study.

\section{Clinical and laboratory assessment}

Height and weight were measured in light clothing without shoes. Body height and weight were measured by a statometer and digital electronic scale, respectively. Body mass index (BMI) was calculated as the patient's weight in kilograms divided by the square of his/her height in meters. The average value of systolic and dia- 
stolic blood pressure measurements were taken with the subject in a sitting position at 2- to 3 -min intervals after resting for at least $15 \mathrm{~min}$.

Serum levels of glucose, total cholesterol, triglyceride, high- and low-density lipoprotein (HDL and LDL) cholesterol, alkaline phosphatase (ALP), calcium and phosphorus were analyzed with commercial kits (Beckman-Coulter Inc., Brea, USA) in an LX-20 autoanalyzer (Beckman-Coulter Inc., Brea, USA). Levels of serum insulin, free T3, free thyroxine (T4), thyroid-stimulating hormone, prolactin, GH, leptin, IGF-1 and insulin-like growth factor-binding protein 3 (IGFB3) were measured in an Immulite 2000 immunoassay analyzer (Siemens Healthcare, Erlangen, Germany) using the chemiluminescence method.

\section{Genetic analysis}

DNA was isolated from peripheral blood with a standard phenol/chloroform extraction method. Genotyping for the $\mathrm{d} 3$ gene was performed by the polymerase chain reaction (PCR) method using a personal thermal cycler (Techgene, USA). PCR was conducted in $50 \mu \mathrm{L}$ reaction mixture containing about $1 \mu \mathrm{g}$ of DNA sample, $5 \mu \mathrm{L}$ reaction buffer (x10) include $160 \mathrm{mM}\left(\mathrm{NH}_{4}\right)_{2} \mathrm{SO}_{4}, 670 \mathrm{mM}$ Tris- $\mathrm{HCl}$ (pH 8.8), 0.1\% Tween-20, $5 \mu \mathrm{L}$ dNTP (2 mM), $3 \mu \mathrm{L} \mathrm{MgCl} 2$ (25 mM), $1 \mathrm{U}$ platinum Taq-polymerase and 100 pmol of each primer. The following primers were used: G1 5'-TGT GCT GGT CTG TTG GTC TG-3', G2 5'-AGT CGT TCC TGG GAC AGA GA-3' and G3 5'-CCT GGA TTA ACA CTT TGC AGA CTC-3' (32). Amplification was performed for 39 cycles comprised of denaturation, extension and annealing at temperatures of $94^{\circ} \mathrm{C}$ for $30 \mathrm{~s}$, $57^{\circ} \mathrm{C}$ for $30 \mathrm{~s}$, and $68^{\circ} \mathrm{C}$ for $30 \mathrm{~s}$, respectively. The final extension time was carried out at $68^{\circ} \mathrm{C}$ for $10 \mathrm{~min}$. The initial denaturation stage was carried out at $95^{\circ} \mathrm{C}$ for $2 \mathrm{~min}$. The fragments obtained were electrophoresed in a $1 \%$ agarose gel and visualized by ethidium bromide staining under ultraviolet (UV) light. The polymorphism detected by PCR was evident as a 935-bp fragment in the presence of the full-length ( $\mathrm{fl} / \mathrm{fl}$ ) fragment and as a 592-bp product in the presence of the deletion $(\mathrm{d} 3 / \mathrm{d} 3)$. Each sample was described as $\mathrm{d} 3 / \mathrm{d} 3, \mathrm{~d} 3 / \mathrm{fl}$, or $\mathrm{fl} / \mathrm{fl}$.

\section{Statistical analysis}

Descriptive statistics, proportions for categorical variables, and means and SDs for continuous variables were used to describe the study groups. Comparisons between acromegalic patients with and without thyroid nodules were made with Student's t-tests. The results were expressed as means \pm standard error. Mann-Whitney $\mathrm{U}$ tests were performed to analyze between-group differences in continuous variables. Values were considered to be statistically significant when $\mathrm{p}<0.05$. Comparisons of gene polymorphisms and leptin levels were made by one- way analysis of variance (ANOVA). Regression analysis was used to tease out the impact of the genotype. All statistical analyses were carried out using SPSS 10.0 software (SPSS Inc., Chicago, USA).

\section{Results}

A total of 24 acromegalic patients were included: 13 males (9 with nodules and 4 without) and 11 females ( 8 with nodules and 3 without). The mean ages of the participants with and without nodules were $51.05 \pm 9.66$ and $54.57 \pm 9.18$, respectively ( $\mathrm{p}>0.05$ ). The participants' anthropometric measurements and blood parameters are shown in Table 1 . In the patients with nodules, statistically significant increases were observed in IGFB3, blood glucose and leptin levels, and decreases were noted for $\mathrm{GH}, \mathrm{BMI}$, homeostasis model assessment (HOMA), LDL and phosphorus (P) levels.

In this study, the frequencies of the GHR-fl/fl, $d 3 / d 3$, and $\mathrm{d} 3 / \mathrm{fl}$ genotypes were $62.5,29.1$, and $8.34 \%$, respectively. There was a strong relationship between gene polymorphism status and leptin levels in acromegalic patients (Table 2). A marked increase was observed in serum leptin levels in patients with the GHR-d3/fl genotype $(\mathrm{p}<0.01)$.

\section{Discussion}

Acromegaly is an acquired disorder related to excessive production of GH and IGF-1 and characterized by progressive somatic disfigurement and systemic manifestations. ${ }^{33}$ Leptin, a neuroregulatory peptide, is secreted by adipose tissue in proportion to adipose content. Because GH modulates fat mass, the study was undertaken to investigate the possible effects of acromegaly on leptin in patients with and without thyroid nodules.

The growth-promoting effects of GH on thyroid follicular cells or a concurrent TSH excess are the conventional hypotheses linking acromegaly to thyrotoxicosis. ${ }^{30}$ Current evidence favors a TSH-independent mechanism in most cases. ${ }^{34}$ In addition, $G$ protein abnormalities can constitutively activate $\mathrm{GH}$-releasing hormone (GHRH) receptors leading to acromegaly, as well as cause constitutive TSH receptor activation leading to thyrotoxicosis. ${ }^{35}$ This may also be a possible mechanism underlying the combination of acromegaly and thyroid nodules studied here.

In this study, serum leptin levels in acromegalic patients with different GHR genotypes (fl/fl, d3/d3, or d3/fl) were examined, and a statistically significant relationship between gene polymorphism status and nodule formation was observed. While no differences were found in homozygous $\mathrm{fl}$ and $\mathrm{d} 3$ patients, a marked predisposition for thyroid nodule development was observed in patients that were heterozygous $(\mathrm{d} 3 / \mathrm{fl})$. Specifically, patients with the GHR-d3/fl genotype exhibited both increased leptin 
Table 1. Mann Whitney U test results of clinical and laboratory characteristics of acromegalic patients with or without thyroid nodule

\begin{tabular}{|c|c|c|c|c|c|c|}
\hline \multirow[t]{2}{*}{ Parameters } & \multicolumn{2}{|c|}{$\begin{array}{l}\text { Acromegalic patient with thyroid } \\
\text { nodule }(n=17)\end{array}$} & \multicolumn{2}{|c|}{$\begin{array}{l}\text { Acromegalic patient without } \\
\text { thyroid nodule }(n=7)\end{array}$} & \multirow[t]{2}{*}{$\mathrm{U}$} & \multirow{2}{*}{$\mathrm{p}$-value } \\
\hline & mean rank & sum of ranks & mean rank & sum of ranks & & \\
\hline BMI $\left(\mathrm{kg} / \mathrm{m}^{2}\right)$ & 14.00 & 238.00 & 8.86 & 62.00 & 34.000 & $<0.05^{*}$ \\
\hline Weight (kg) & 13.38 & 227.50 & 10.36 & 72.50 & 44.500 & ns \\
\hline Fasting glucose (mg/dL) & 14.41 & 245.00 & 7.86 & 55.00 & 27.000 & $<0.05^{*}$ \\
\hline Insulin ( $\mu \mathrm{lU} / \mathrm{mL})$ & 13.53 & 203.00 & 10.00 & 70.00 & 42.000 & ns \\
\hline HOMA & 13.97 & 237.50 & 8.93 & 62.50 & 34.500 & $<0.05^{*}$ \\
\hline $\mathrm{GH}(\mathrm{ng} / \mathrm{L})$ & 11.97 & 203.50 & 15.79 & 96.50 & 50.500 & $<0.05^{*}$ \\
\hline IGF1 (ng/L) & 12.76 & 217.00 & 11.86 & 83.00 & 55.000 & ns \\
\hline Total cholesterol (mg/dL) & 13.41 & 228.00 & 10.29 & 72.00 & 44.000 & ns \\
\hline Triglyceride (mg/dL) & 13.35 & 227.00 & 10.43 & 73.00 & 45.000 & ns \\
\hline $\mathrm{LDL}(\mathrm{mg} / \mathrm{dL})$ & 12.12 & 206.00 & 13.43 & 94.00 & 53.000 & ns \\
\hline $\mathrm{HDL}(\mathrm{mg} / \mathrm{dL})$ & 12.26 & 208.50 & 13.07 & 91.50 & 55.000 & ns \\
\hline TSH ( $\mu \mathrm{IU} / \mathrm{mL})$ & 12.94 & 220.00 & 11.43 & 80.00 & 52.000 & ns \\
\hline Leptin (ng/mL) & 13.24 & 225.00 & 9.71 & 75.00 & 47.000 & $<0.05^{*}$ \\
\hline FT3 (pg/mL) & 12.15 & 206.50 & 13.36 & 93.50 & 53.500 & ns \\
\hline FT4 (ng/dL) & 11.97 & 203.50 & 13.79 & 96.50 & 50.500 & ns \\
\hline $\operatorname{COR}(\mu \mathrm{g} / \mathrm{dL})$ & 13.26 & 225.50 & 10.64 & 74.50 & 46.000 & ns \\
\hline $\mathrm{PRL}(\mathrm{ng} / \mathrm{mL})$ & 12.88 & 219.00 & 11.57 & 81.00 & 53.000 & ns \\
\hline $\mathrm{CA}(\mathrm{mg} / \mathrm{dL})$ & 12.29 & 209.00 & 13.00 & 91.00 & 56.000 & ns \\
\hline Right thyroid lobe (mm) & 12.38 & 210.50 & 12.79 & 89.50 & 57.500 & ns \\
\hline Left thyroid lobe (mm) & 13.21 & 224.50 & 10.79 & 75.50 & 47.500 & ns \\
\hline Isthmus (mm) & 10.22 & 163.50 & 14.92 & 89.50 & 27.000 & ns \\
\hline
\end{tabular}

ns - non-significant, ${ }^{*}$ significant differences between the groups $(p<0.05)$.

Table 2. GHR gene polymorphisms; leptin, IGF-1, and GH levels; and BMI in acromegalic patients with or without thyroid nodule

\begin{tabular}{|c|c|c|c|c|c|}
\hline Patients & $\mathrm{n}$ & Leptin level & BMI & IGF-1 & $\mathrm{GH}$ \\
\hline fl/fl genotypes with nodule & 11 & $6.44 \pm 9.09^{a}$ & $28.70 \pm 4.61$ & $740.54 \pm 326.89$ & $15.77 \pm 11.96$ \\
\hline $\mathrm{fl} / \mathrm{fl}$ genotypes without nodule & 4 & $3.25 \pm 4.74^{\mathrm{a}}$ & $25.72 \pm 2.99$ & $436.50 \pm 300.98$ & $9.86 \pm 7.07$ \\
\hline d3/d3 genotypes with nodule & 4 & $7.57 \pm 8.60^{a}$ & $28.60 \pm 2.65$ & $393.50 \pm 272.94$ & $5.36 \pm 3.37$ \\
\hline d3/d3 genotypes without nodule & 3 & $4.79 \pm 2.80^{a}$ & $26.93 \pm 1.66$ & $1045.00 \pm 677.62$ & $31.43 \pm 25.93$ \\
\hline d3/fl genotypes with nodule & 2 & $28.19 \pm 3.46^{b}$ & $35.15 \pm 0.63$ & $563.00 \pm 216.37$ & $4.96 \pm 9.19$ \\
\hline$p$-value & & $<0.01^{* *}$ & ns & ns & ns \\
\hline
\end{tabular}

** The differences between the means of groups carrying different letters in the same column are statistically significant ( $p<0.01)$, ns - non-significant.

levels and a predisposition to nodule formation. Notably, nodules were found in all patients with the GHR-d3/fl genotype (Table 2).

GH plays an important role in the regulation of adiposity and modulates fat deposition and accumulation via regulatory molecules in preadipocytes and adipocytes. ${ }^{36}$ Some authors have reported that GH excess is associated with decreased leptin levels and decreased fat mass. ${ }^{37}$ In con- trast, the present study found that increased leptin levels were associated with decreased GH levels in acromegalic patients with thyroid nodules. Lower leptin levels have been reported in acromegalic patients. ${ }^{1,38}$ Different treatments for acromegaly lead to increased leptin levels. ${ }^{39-41}$ Collectively, the evidence indicates that leptin secretion is reduced in active acromegaly, presumably reflecting reduced body fat stores. Restoration of GH secretion is as- 
sociated with an increase in leptin levels, probably due to an increase in fat stores. ${ }^{1}$ Leonhardt et al. reported a significant increase in serum leptin levels in a hypothyroid patient compared to hyperthyroid and normal controls. ${ }^{42}$ Similar results were reported by Yoshida et al. ${ }^{43}$ Leptin is also related to the progression of some tumors, including thyroid cancers. ${ }^{18-22,24-27}$

In the present study, a marked increase in leptin levels was observed in acromegalic patients with thyroid nodules compared to those without. These findings indicate that the thyroid may have a greater effect on leptin levels than the pituitary. The mechanism underlying the link between leptin and LDL levels is not clear. However, some authors have reported that leptin has a pro-oxidant effect. Previous reports have described leptin having a direct effect on endothelial cell generation of reactive oxygen species that have been shown to play a role in LDL oxidation. ${ }^{44-46}$ In this study, decreased LDL levels may be related to higher leptin levels in acromegalic patients with thyroid nodules.

GHR polymorphism has been reported in acromegaly,but to the best of the authors' knowledge, this is the first study investigating anthropometric measurements, blood parameters and gene polymorphism in acromegalic patients with or without thyroid nodules. ${ }^{32}$ Although the study included only a small group of patients because of the rarity of the combination of the 2 conditions and the unusual inclusion criteria, the results indicate that thyroid nodules are associated with changes in some parameters in acromegalic patients. Practitioners need to take these results into consideration when treating acromegalic patients. At the same time, although the GHR-d3/fl genotype was a predisposing factor in acromegalic patients in this study, there were no differences in IGF-1 levels in these patients. The possible cause of this may be related to other growth factors, and higher leptin levels may contribute to thyroid nodule development. This is a preliminary result, and further studies are needed.

\section{References}

1. Katznelson L. Alterations in body composition in acromegaly. Pituitary. 2009;12(2):136-142.

2. Tunbridge WMG, Evered DC, Hall R, et al. The spectrum of thyroid disease in a community: The Whickham Survey. Clin Endocrinol (Oxf). 1977;7(6):481-493.

3. Vander JB, Gaston EA, Dawber TR. The significance of nontoxic thyroid nodules. Final report of a 15-year study of the incidence of thyroid malignancy. Ann Intern Med. 1968;69(3):537-540.

4. Tan GH, Gharib H. Thyroid incidentalomas: Management approaches to nonpalpable nodules discovered incidentally on thyroid imaging. Ann Intern Med. 1997;126(3): 226-231.

5. Gasperi M, Martino E, Manetti L, et al. Acromegaly study group of Italian Society of Endocrinology: Prevalence of thyroid diseases in patients with acromegaly: Results of an Italian multicenter study. $J$ Endocrinol Invest. 2002;25(3):240-245.

6. Herrmann BL, Baumann $\mathrm{H}$, Janssen OE, Gorges R, Schmid KW, Mann K. Impact of disease activity on thyroid diseases in patients with acromegaly: Basal evaluation and follow-up. Exp Clin Endocrinol Diabetes. 2004;112(5):225-230.
7. Miyakawa M, Saji M, Tsushima T, Wakai K, Shizume K. Thyroid volume and serum thyroglobulin levels in patients with acromegaly: Correlation with plasma insulin-like growth factor 1 levels. J Clin Endocrinol Metab. 1988;67(5):973-978.

8. Geelhoed-Duijvestijn PH, Bussemaker JK, Roelfsema F. Changes in basal and stimulated TSH and other parameters of thyroid function in acromegaly after transsphenoidal surgery. Acta Endocrinol. 1989;121(2):207-215.

9. Roelfsema F, Frolich M. Pulsatile thyrotropin release and thyroid function in acromegalics before and during subcutaneous octreotide infusion. J Clin Endocrinol Metab. 1991;72 (1):77-82.

10. Baldys-Waligorska A, Krzentowska A, Golkowski F, Sokolowsk G, Hubalewska-Dydejczyk A. The prevalence of benign and malignant neoplasms in acromegalic patients. Endokrynol Pol. 2010;61(1): 29-34.

11. Rowland NE, Morien A, Li BH. The physiology and brain mechanisms of feeding. Nutrition. 1996;12(9):626-639.

12. Licinio J, Negrao AB, Mantzoros C, et al. Sex differences in circulating human leptin pulse amplitude: clinical implications. J Clin Endocrinol Metab. 1998;83(11):4140-4147.

13. Lonnqvist F, Wennlund A, Arner P. Relationship between circulating leptin and peripheral fat distribution in obese subjects. Int J Obes Relat Metab Disord. 1997;21(4):255-260.

14. EscobarMorreale HF, delRey FE, deEscobar GM. Thyroid hormones influence serum leptin concentrations in the rat. Endocrinology. 1997;138(10);4485-4488.

15. Santini F, Marsili A, Mammoli C, et al. Serum concentrations of adiponectin and leptin in patients with thyroid dysfunctions. J Clin Endocrinol Invest. 2004;27(2):RC5-RC7.

16. Sesmilo G, Casamitjana R, Halperin I, Gomis R, Vilardell E. Role of thyroid hormones on serum leptin levels. Eur J Endocrinol. 1998;139(4):428-430.

17. Sreenan S, Caro JF, Refetoff S. Thyroid dysfunction is not associated with alterations in serum leptin levels. Thyroid. 1997;7(3):407-409.

18. Brauner R, Trivin C, Zerah M, et al. Diencephalic syndrome due to hypothalamic tumour: A model of the relationship between weight and puberty onset. J Clin Endocrinol Metab, 2006;91(7):2467-2473.

19. Garofalo C, Surmacz E. Leptin and cancer. J Cell Physiol. 2006;207(1): 12-22.

20. Hoda MR, Keely SJ, Bertelsen LS, Junger WG, Dharmasena D, Barrett $\mathrm{KE}$. Leptin acts as a mitogenic and antiapoptotic factor for colonic cancer cells. Brit J Surg. 2007;94(3):346-354.

21. Jaffe T, Schwartz B. Leptin promotes motility and invasiveness in human colon cancer cells by activating multiple signal-transduction pathways. Int J Cancer. 2008;123(11):2543-2556.

22. Li L, Gao Y, Zhang LL, He DL. Concomitant activation of the JAK/ STAT3 and ERK1/2 signaling is involved in leptin-mediated proliferation of renal cell carcinoma Caki-2 cells. Cancer Biol Therapy. 2008;7(11):1787-1792.

23. O'Brien SN, Welter BH. Price TM. Presence of leptin in breast cell lines and breast tumors. Bioch Bioph Res Co. 1999;259(3):695-698.

24. Ribeiro R, Arauj A, Lopes C, Medeiros R. Immunoinflammatory mechanisms in lung cancer development: Is leptin a mediator? J Thorac Oncol. 2007;2(2):105-108.

25. Mantzoros CS, Rosen HN, Greenspan SL, Flier JS, Moses AC. Shortterm hyperthyroidism has no effect on leptin levels in man. J Clin Endocrinol Metab. 1997;82(2):497-499.

26. Uddin S, Bavi P, Siraj AK, et al. Leptin-R and its association with PI3K/AKT signaling pathway in papillary thyroid carcinoma. Endocr Relat Cancer. 2010;17(1):191-202.

27. Valcavi R, Zini M, Peino R, Casanueva FF, Dieguez C. Influence of thyroid status on serum immunoreactive leptin levels. J Clin Endocrinol Metab. 1997;82(5):1632-1634.

28. Toyoshiman MT, Castroneves LA, Costalonga EF, et al. Exon 3-deleted genotype of growth hormone receptor (GHRd3) positively influences IGF-1 increase at generation test in children with idiopathic short stature. Clin Endocrinol. 2007;67(4):500-504.

29. Cheung NW, Boyages SC. The thyroid gland in acromegaly: An ultrasonographic study. Clin Endocrinol. 1997;46(5):545-549.

30. Kasagi K, Shimatsu A, Miyamoto S, Misaki T, Sakahara H, Konishi J. Goiter associated with acromegaly: sonographic and scintigraphic findings of the thyroid gland. Thyroid. 1999;9(8):791-796. 
31. Freda PU. Current concepts in the biochemical assessment of the patient with acromegaly. Growth Horm IGF Res. 2003;13:171-184.

32. Montefusco L, Filopanti $\mathrm{M}$, Ronchi $\mathrm{CL}$, et al. d3-Growth hormone receptor polymorphism in acromegaly: Effects on metabolic phenotype. Clin Endocrinol. 2010;72(5):661-667.

33. Holdaway IM, Rajasoorya C. Epidemiology of acromegaly. Pituitary. 1999;2(1):29-41.

34. Marzullo P, Cuocolo A, Ferone D, et al. Cardiac effect of thyrotoxicosis in acromegaly. J Clin Endocrinol Metab. 2000;85(4):1426-1432.

35. Spada A, Lania A, Ballare E. G protein abnormalities in pituitary adenomas. Mol Cell Endocrinol. 1998;25(142):1-14.

36. Bluher S, Kratzsch J, Kiess W. Insulin-like growth factor I, growth hormone and insulin in white adipose tissue. Best Pract Res Clin Endocrinol Metab. 2005;19(4):577-587.

37. Damjanovic SS, Petakov MS, Raicevic S, et al. Serum leptin levels in patients with acromegaly before and after correction of hypersomatotropism by trans-sphenoidal surgery. J Clin Endocrinol Metab. 2000;85(1):147-154.

38. Bolanowski M, Milewicz A, Bidzinska B, Jedrzejuk D, Daroszewski J, Mikulski E. Serum leptin levels in acromegaly - a significant role for adipose tissue and fasting insulin/glucose ratio. Med Sci Monit. 2002;8:CR685-CR689.

39. Paramo C, Fluiters E, de la Fuente J, Andrade A, Garcia-Mayor RV. Monitoring of treatment success in patients with acromegaly: The value of serum insulin-like growth factor binding protein-3 and serum leptin measurements in comparison to plasma insulin-like growth factor I determination. Metabolism. 2001;50(9):1117-1121.
40. Parkinson C, Whatmore AJ, Yates AP, et al. The effect of pegvisomant-induced serum IGF-I normalization on serum leptin levels in patients with acromegaly. Clin Endocrinol (Oxf). 2003;59(2):168-174.

41. Tan KC, Tso AW, Lam KS. Effect of Sandostatin LAR on serum leptin levels in patients with acromegaly. Clin Endocrinol (Oxf). 2001; 54(1):31-35.

42. Leonhardt U, Ritzel U, Schafer G, Becker W, Ramadori G. Serum leptin levels in hypo- and hyperthyroidism. J Endocrinol. 1998;157(1): 75-79.

43. Yoshida T, Momotani N, Hayashi M, Monkawa T, Ito K, Saruta T. Serum leptin concentrations in patients with thyroid disorders. Clin Endocrinol. 1998;48(3):299-302.

44. Bouloume A, Marumo T, Lafontan M, Busse R. Leptin induces oxidative stress in human endothelial cells. FASEB J. 1999;13(10):12311238.

45. Yamagishi SI, Edelstein D, Du XL, Kaneda Y, Guzman M, Brownlee $M$. Leptin induces mitochondrial superoxide production and monocyte chemoattractant protein-1 expression in aortic endothelial cells by increasing fatty acid oxidation via protein kinase. J Biol Chem. 2001;276(27):25096-25100.

46. Holvoet P, Collen D. Oxidized lipoproteins in atherosclerosis and thrombosis. FASEB J. 1994;8(15):1279-1284. 